\title{
Microvascular bioengineering: a focus on pericytes
}

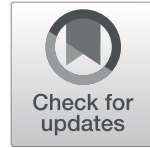

Huaning Zhao ${ }^{1,2}$ and John C. Chappell ${ }^{1,2,3^{*}}$

\begin{abstract}
Capillaries within the microcirculation are essential for oxygen delivery and nutrient/waste exchange, among other critical functions. Microvascular bioengineering approaches have sought to recapitulate many key features of these capillary networks, with an increasing appreciation for the necessity of incorporating vascular pericytes. Here, we briefly review established and more recent insights into important aspects of pericyte identification and function within the microvasculature. We then consider the importance of including vascular pericytes in various bioengineered microvessel platforms including 3D culturing and microfluidic systems. We also discuss how vascular pericytes are a vital component in the construction of computational models that simulate microcirculation phenomena including angiogenesis, microvascular biomechanics, and kinetics of exchange across the vessel wall. In reviewing these topics, we highlight the notion that incorporating pericytes into microvascular bioengineering applications will increase their utility and accelerate the translation of basic discoveries to clinical solutions for vascular-related pathologies.
\end{abstract}

Keywords: Pericytes, Endothelial cells, Capillary, Microfluidics, Computational modeling

\section{Background}

Oxygen, nutrients, and immune cells are among the many critical elements contained in blood that circulates throughout the human vascular system [1]. The interconnected blood vessels comprising this system are therefore essential for sustaining the health and homeostasis of the tissues and organs in which they reside [2]. Arteries carrying oxygenated blood from the heart ramify into smaller diameter arterioles. Vascular smooth muscle cells (vSMCs) wrap around these vessels to distribute blood into even smaller diameter capillaries where oxygen diffusion and nutrient delivery primarily occur [3]. These intricate microvascular networks also facilitate the removal of carbon dioxide and cellular waste from all tissues. These and other byproducts are returned into the systemic circulation for clearance via small-diameter venules that converge into larger veins. Because microvessels (i.e. blood vessels with a diameter of less

\footnotetext{
* Correspondence: JChappell@vtc.vt.edu

${ }^{1}$ Center for Heart and Reparative Medicine, Fralin Biomedical Research Institute, 2 Riverside Circle, Roanoke, VA 24016, USA

${ }^{2}$ Department of Biomedical Engineering and Mechanics, Virginia Polytechnic State Institute and State University, Blacksburg, VA 24061, USA

Full list of author information is available at the end of the article
}

than $10 \mu \mathrm{m})$ are such a vital component of the vascular system [4], significant effort has been made to engineer various platforms to better understand the biology of the microcirculation as well as to develop clinically relevant, vascular-focused therapies.

The field of vascular bioengineering includes a focus on microvessels and generating functional capillary networks $[5,6]$ but also encompasses advancing biotechnologies to synthesize larger diameter vessels for bypass grafts $[7,8]$, for example. Thus, to delineate the scope of this review, we will focus on "microvascular bioengineering", that is, the biology and technological developments relevant to capillary-sized vessels. As discussed above, the microcirculation is fundamental to the metabolic exchange that sustains every tissue of the human body. Microvessels also regulate the movement of fluid and other solutes across the blood vessel wall [9-14]. The endothelial cells that compose the inner surface of all blood vessels are integral in maintaining this barrier function. Endothelial cells form a selective barrier by assembling various types of junctions amongst themselves including adherins junctions via vascular endothelial-cadherin (VE-Cadherin, or Cadherin5) [15-18] and, highly enriched in neural tissues, tight junctions using zona occludins-1 (ZO-1), claudin5, and/or

(c) The Author(s). 2019 Open Access This article is distributed under the terms of the Creative Commons Attribution 4.0 International License (http://creativecommons.org/licenses/by/4.0/), which permits unrestricted use, distribution, and 
occludin [11]. Microvascular bioengineering approaches often focus on the formation of these junctions as an important read-out for the success of a particular platform. Equally as important for promoting microvessel barrier function are vascular pericytes [11, 12, 19-21], a cell type that remains poorly understood relative to endothelial cells and is only beginning to be considered in microvascular bioengineering applications.

\section{Pericyte identity}

Pericytes extend along nearly every capillary within the human body, making direct contact with the underlying endothelium and embedded within the vascular basement membrane (vBM). Rouget and Eberth are credited with first distinguishing these cells from vSMCs by noting their unique appearance [22-24]. Specifically, pericytes were identified in perivascular locations but elongated along capillaries, at microvessel branch points and along microvascular segments resembling "bumps-on-a-log" [25] (Fig. 1). Scanning electron microscopy further confirmed their formation of "peg-and-socket" junctions with endothelial cells, and their presence within the vBM, a specialized extracellular matrix (ECM) that surrounds the vascular unit. Vascular pericytes likely arise during embryonic development from unique cellular niches that depend on the specific tissue and organ. Nonetheless, neural crest and primordial mesenchyme are frequently noted as giving rise to pericytes [20, 26-28], with hematopoietic origins also being described (though these may be present primarily during angiogenesis and less so during vessel maturation) [29]. Pericytes depend heavily on platelet-derived growth factor-BB (PDGF-BB) signaling for their recruitment and retention along vessels [30-36]. They highly express PDGF Receptor- $\beta$ (PDGFR $\beta$ ), which is a useful cell surface marker for identifying pericytes on capillary branches within many tissues, though interpretation of this signal must also include a consideration that vSMCs and certain brain glia also express PDGFR $\beta$ [33, 37, 38]. Neural glial antigen-2 (NG2, gene name: chondroitin sulfate proteoglycan-4, Cspg4) is also a helpful marker for pericytes, though oligodendrocyte precursor cells (OPCs) in the brain also express NG2/Cspg4 [39-41]. Because of this overlap in marker expression, no single marker, or even combination of markers, can be used to specifically identify pericytes. Next-generation sequencing and single-cell profiling techniques will likely yield a more specific marker for pericytes [42-48], but coupling marker expression with morphological features currently offers a high degree of confidence in identifying microvascular pericytes [49].

As criteria for bona fide pericytes continue to strengthen [50], it is becoming possible to identify pericyte subtypes that correspond to their locations within

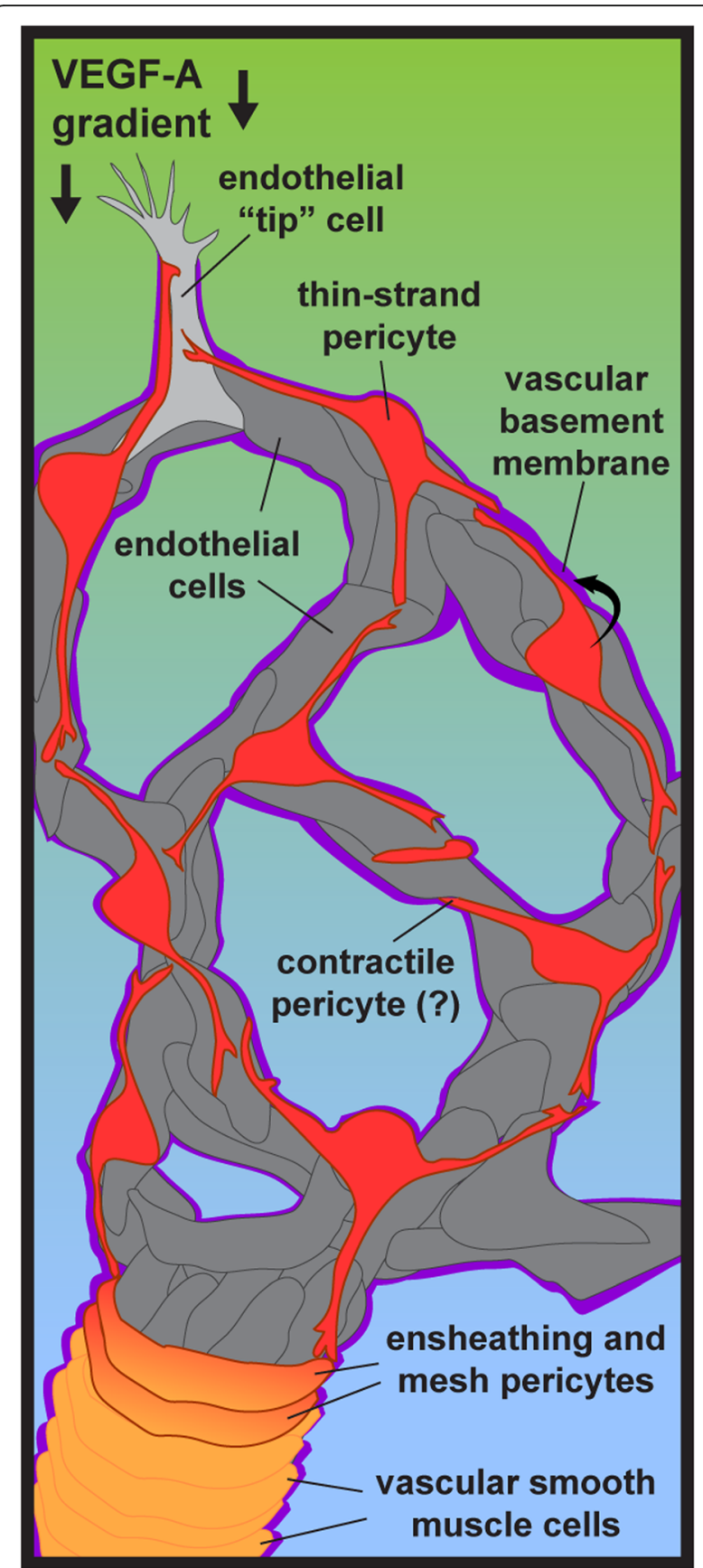

Fig. 1 Simplified schematic of pericytes within the microcirculation. During angiogenic remodeling of microvessels, pericytes migrate along endothelial "tip" cells and secrete extracellular matrix components into the vascular basement membrane. Pericytes establish non-overlapping spatial domains, and a subset of pericytes may modulate microvessel diameter. Pericytes closer to terminal arterioles may wrap around and ensheath vessels, though these cells are likely distinct from vascular smooth muscle cells

a microvascular network. Grant et al. for example recently conducted a thorough analysis of microvessels in the mouse brain using two-photon and confocal imaging in conjunction with tissue clearing techniques 
[51]. The authors were able to classify pericytes into three unique categories: 1- ensheathing pericytes (on pre-capillary arterioles), 2- mesh pericytes [on capillaries just downstream of ensheathing pericytes containing $\alpha$-smooth muscle actin ( $\alpha \mathrm{SMA})]$, and 3- thin-strand pericytes (on capillaries immediately adjacent to mesh pericytes) (Fig. 1). Even within these subpopulations, pericytes appear to maintain non-overlapping spatial domains along the microvasculature. These potential distinctions between pericyte subtypes suggest that each subpopulation may play diverse roles within the microcirculation in addition to a subset of common functions [51-54]. Additional studies will be necessary to determine if functional differences do indeed exist among pericyte subtypes, as well as if these pericyte subpopulations are present in other tissues and organs beyond the brain [42]. Complementary imaging approaches will also be useful in characterizing potential pericyte subtypes. Imaging modalities such as super-resolution microscopy, scanning electron microscopy (SEM) [55], and serial block face-SEM [56] can capture ultra-structural details that are likely beyond the resolution of optical microscopes but could be important in understanding the configuration of these pericyte subtypes.

Continued advancement of pericyte-specific tools and markers alongside next-generation imaging and sequencing modalities will not only illuminate distinctions between pericyte subtypes, but will also offer more insight into how pericytes differ from other cell types the reside in perivascular locations. For instance, gross pericyte morphology is well known to contrast with that of vSMCs, which concentrically wrap around endothelial cells in a configuration consistent with their primary role in regulating vascular tone. In spite of these and other distinctions, pericytes have often been grouped together with vSMCs and labeled as "mural cells" [57-59]. Pericytes may indeed give rise to vSMCs as seen in the development of mouse coronary arteries [60]. Distinct molecular signals such as those from the Notch pathway coordinate this pericyte-to-vSMC transition, but these cues do not appear to be required for pericyte differentiation, recruitment, or retention within the microcirculation [37, 61-64]. Pericytes have also been associated with and classified as "perivascular fibroblasts" [58], despite the fact that fibroblasts are rarely, if ever, embedded within the vBM as pericytes are. Additionally, pericytes have been described as perivascular mesenchymal stem cells (MSCs) capable of trans-differentiation and tissue regeneration [53, 65-70], though this identity may be context- and/or model-dependent $[67,71-80]$. Therefore, as progress continues in developing markers and tools to identify pericytes and distinguish them from other cell types, microvascular bioengineering approaches will be able to incorporate these essential cells to enhance our understanding of the microcirculation and to generate clinically relevant, microvessel-focused therapies.

\section{Pericyte function}

Pericytes play a variety of important roles in the development, maturation, and functionality of microvascular networks. During the growth of new blood vessel from pre-existing vessels, a process known as angiogenesis, pericytes dynamically interact with endothelial "tip" cells that sprout to form new branches [81-86]. We are just beginning to understand pericyte-endothelial cell crosstalk during sprouting angiogenesis, but what is clear is that pericytes modulate the stability of newly formed microvessel branches [87] and structurally maintain capillary diameter within an appropriate range $[88,89]$ (Fig. 1). Pericytes also promote and sustain the integrity of the microvessel wall by stimulating endothelial cell junction formation [12-14], as discussed above. In the brain, pericytes appear to provide a level of regulation for the movement of solutes across the vessel wall through transcytosis and vesicular transport [12]. Pericytes also regulate the composition of the blood vessel wall by synthesizing and depositing specific elements within the vBM $[20,88,90,91]$. Fibronectin, vitronectin, laminins, and Type IV collagen (Col-IV) are among the extracellular matrix (ECM) components that pericytes secrete into the microvessel wall [43, 92] (Fig. 1). In addition to structural regulation of the capillary wall, pericytes have been implicated in dynamic modulation of microvessel tone and diameter, particularly in the central nervous system (CNS) [26, 93-101]. Although pericyte contractility remains an open question [94, 102], recent observations of calcium fluctuations in brain pericytes suggests that they participate at some level in mechanisms coordinating blood flow regulation with region-specific metabolic demand [52]. These diverse roles for pericytes within the microcirculation underscore their importance in maintaining tissue health by promoting and sustaining microvessel stability, barrier function, and perfusion.

Beyond their contribution to vascular-specific functions, pericytes have been implicated in other biological processes, both physiological and pathological. For instance, pericytes have been described as MSCs occupying perivascular locations, suggesting that a subset of vascular pericytes may actually be capable of tissue regeneration [53, 54, 66-68]. A recent study by Guimarães-Camboa and colleagues suggests that we may need to reconsider this role in vivo however, as they found pericytes derived from multiple organs demonstrated lineage plasticity (i.e. pluripotency as MSCs) only when cultured in vitro [80]. Pericyte contributions to certain disease processes have also been reported. In 
proliferative diabetic retinopathy, "pericyte dropout" (and thus destabilization of the retina capillary wall) is thought to be a key step in the progression of this disorder [103-105]. This loss of pericytes may occur through apoptosis and cell death [106], but may also result from pericyte detachment and emigration away from the microvessel wall $[107,108]$. This mode of pericyte loss has been implicated in other disease conditions as well, notably idiopathic pulmonary fibrosis (IPL) [108] and kidney fibrosis $[109,110]$, among others. In pathologies of fibrosis, pericytes have been identified as major producers of ECM components that exacerbate the fibrotic content of affected tissues and organs [65, 108112]. An emerging role for pericytes in certain pathological states is their aberrant progression towards a more highly contractile phenotype, as suggested by a notable increase in expression of vasomotor proteins such as $\alpha$ SMA (i.e. hyper-muscularization). In a model of defective col-IV synthesis, for example, pericytes have been shown to acquire higher levels of $\alpha$ SMA $[113,114]$, as we have also seen in a model of perturbed oxygen sensing [i.e. via mutations in the von Hippel-Lindau (VHL) gene] [115]. Pathological pericyte vasocontractility may adversely affect blood flow within the microcirculation [93, 94, 96, 116] and undermine pressure regulation, which could in turn increase the risk for vessel rupture. Further investigation will be needed to understand the underlying mechanisms that may aberrantly drive pericytes towards a contractile phenotype.

New insights into pericyte biology have emerged with the recent flourish of interest regarding pericyte identity, differentiation, and function within the microcirculation. More detailed understanding of established functions as well as novel roles are still being elucidated, inspiring many thoughtful and comprehensive reviews $[14,19,20$, $25,117-120]$. Indeed, a wide range of intriguing pericyte-focused studies have recently been contributed to the scientific literature; space limitations however prevent an exhaustive review of all of these interesting discoveries. Nevertheless, in this review, we focus on the importance of incorporating pericytes into engineered microvascular constructs across a variety of platforms. We give specific consideration to incorporating pericytes (i) into bioengineered vessels for exploratory purposes and for potential therapeutic applications, and (ii) into computational models of vascular-specific processes.

\section{Incorporating Pericytes into bioengineered microvessels}

The most simplified models of the blood vasculature are often endothelial cell-based, mostly in 2D on cell culture plastic and under static conditions. Human umbilical vein endothelial cells (HUVECs) have served as a predominant source for the cell line utilized, though additional sources have been developed including microvascular endothelial cells. Embryonic stem cells (ESCs) [121-124] as well as induced pluripotent stem cells (iPSCs) [125] have also been used to generate endothelial cells. These basic 2D models were further developed in unique ways to address specific research questions. Endothelial cells and differentiated ESCs and iPSCs have been embedded in 3D matrixes such as Type I Collagen (Col-I) $[126,127]$ or fibrinogen $[128,129]$ to investigate vascular remodeling processes such as sprouting angiogenesis and vessel lumen formation [130]. In 2D platforms, endothelial cells have also been subjected to fluid movement and shear stress by a variety of methods $[8$, 131-135]. These studies in particular ushered in tremendous insight into the coupling between fluid mechanics and endothelial cell biology, including concepts such as endothelial mechano-transduction [136]. Fluidics platforms recapitulating fluid flow across cells in initial configurations were likely more comparable to scenarios of larger diameter vessels. Capillary-like fluidic systems however were relatively limited until the advent of microfluidics technology.

For the models aiming to mimic the microvasculature, incorporation of pericytes represents a logical next step in building complexity and moving closer to modeling in vivo microvessels. Several challenges exist in establishing standard methods to isolate and culture purified pericytes for in vitro use. Because pericyte markers overlap with other cell types, selecting pericyte populations via marker expression (i.e. for magnetic- or fluorescent reporter-based sorting) can yield isolates that are enriched but not necessarily pure. The same obstacles limit validation approaches using certain markers in expression analysis by qRT-PCR and Western Blot, though combinatorial approaches can be useful. An additional challenge in validating pericyte identity in vitro is that their cell fate plasticity may depend heavily on culture conditions [80]. Given that pericyte functions are tightly coupled to endothelial cell activities such as barrier function as well as angiogenic sprouting and remodeling [50, 137], validation strategies that rigorously test for these key features of microvascular pericyte identity, even applied to commercially available cell lines, will bolster confidence in techniques used for their isolation and culture. Similar strategies may also need to be developed for exploring the potential stem cell properties of pericytes, which may exhibit broad plasticity after dissociation from the vessel wall.

Pericyte-endothelial cell co-culture models provide insight into how certain experimental perturbations might affect each cell type directly and perhaps indirectly [57]. Similarly, 3D co-culture [84, 88] or stem cell-based [126, 127, 138] models of vascular remodeling and sprouting angiogenesis capture the unique 
contributions of both cell types to these processes. Vessel-like structures form within these 3D in vitro models via coalescence of cells into basic vascular networks (i.e. resembling in vivo vasculogenesis such as in the yolk sac $[139,140])$. Primitive vasculature in these models can also arise through subsequent endothelial cell sprouting and angiogenic remodeling as observed in vivo in tissues such as the developing mouse retina [115, 141]. Although these 3D in vitro models cannot recapitulate all aspects of the corresponding in vivo scenarios such as including blood flow, oxygen gradients, and the full range of relevant cell types, coupling these models with synthetic or naturally occurring ECM scaffolds [142-144] may also shed light on disease-related phenomena. Pericyte migration away from vessels, as seen in diabetic retinopathy and IPL discussed above, has been successfully modeled with such systems [108].

Incorporating pericytes into vascular fluid mechanics models has been uniquely challenging. A distinct spatial configuration is required for such a platform, that is, positioning endothelial cells only on the "luminal" side while not exposing pericytes to fluid flow on the "abluminal" side. Thus, microfluidic approaches have offered a viable means to create endothelialized micro-channels (i.e. microvessel-like structures) $[142,145,146]$ that can be adapted to include pericytes alongside these channels (Fig. 2a). Work from the labs of Steven George and
Chris Hughes has yielded one such microfluidics platform that reproducibly develops perfused vessels and allows incorporation of other cell types including pericytes [147-149]. These types of bioengineered microvessels can be further adapted and interrogated to better understand the interface between the microcirculation and cells in the surrounding parenchyma. Blood-brain barrier models for example integrate brain astrocytes (either in basic co-culture and in microfluidics devices) [9] to gain insight into how this uniquely selective barrier is formed and how certain pharmacological agents might transiently disrupt it $[10,150]$. Additionally, interactions between surrounding tumor cells and microvessels can be explored in these models to explore effects of chemotherapeutic compounds, efficacy of drug delivery vehicles such as nanoparticles [151, 152], and assessing toxicity profiles for the microvasculature [147]. Bioengineered microvascular fluidics platforms offer tools to better understand the microcirculation during formation of microthrombi and acute pressure changes that might lead to microvessel rupture [153], the risk for which may vary according to pericyte investment. Mechanisms underlying extravasation of leukocytes and perhaps even metastatic tumor cells might also be addressed in these constructs [148]. Pericytes and endothelial cells likely coordinate the selective permeability of the microvessel wall to allow cells to transmigrate from the lumen into
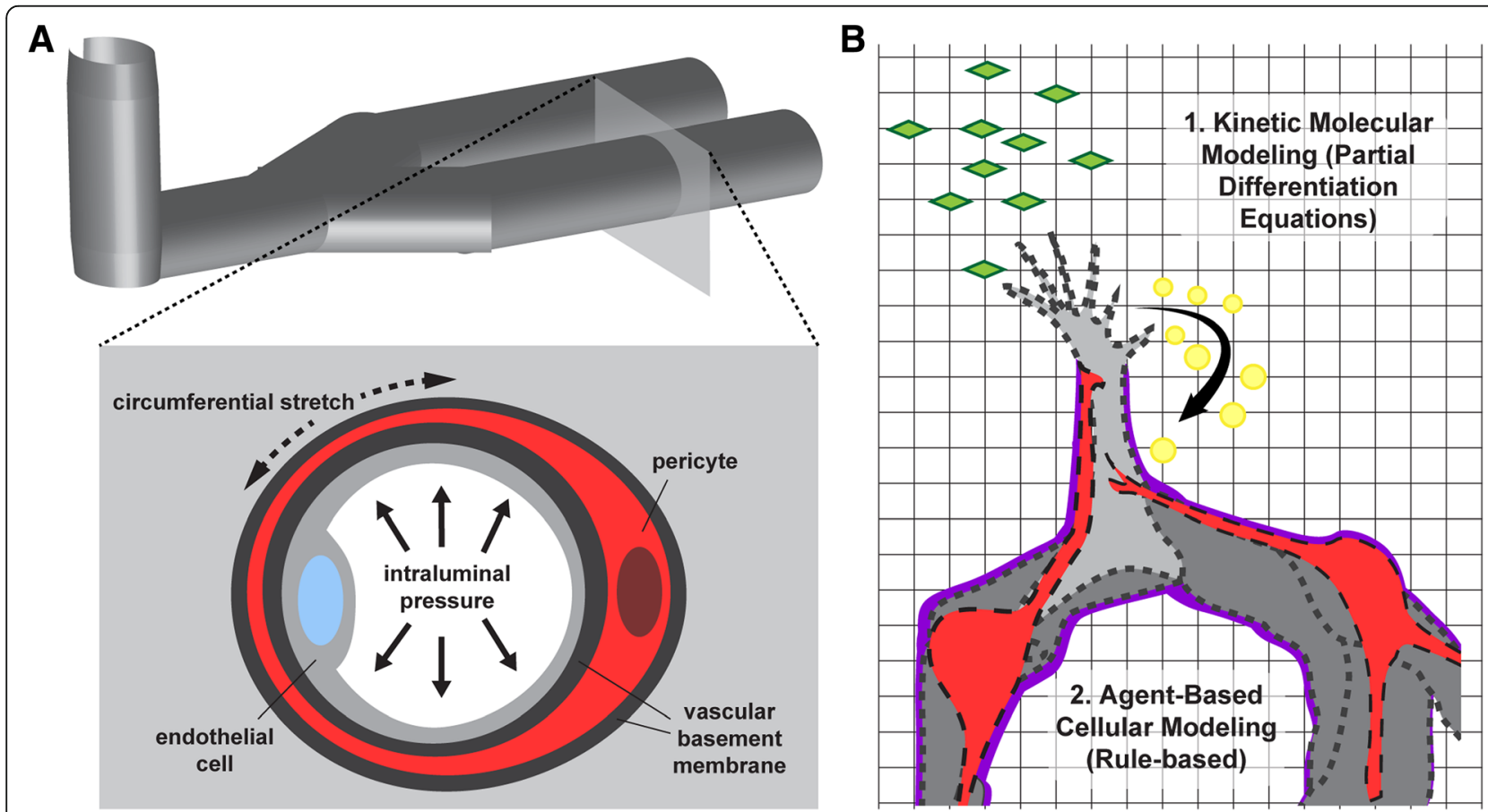

Fig. 2 Microvascular bioengineering applications in which pericyte incorporation is relevant. a Microfluidic platforms simulating capillaries can address numerous questions regarding pericyte biology including their response to intraluminal pressure dynamics and associated circumferential stresses. b Integration of kinetic and agent-based models, such as the one depicted in this simplified illustration, represent how multi-scale computational models might incorporate pericytes to enhance their ability to recapitulate biological processes such as angiogenesis 
the interstitial space [21]. For instance, pericytes may alter their connections with each other and the endothelium, as well as the surrounding vBM, in conjunction with endothelial cell remodeling of their cell-cell junctions [17]. As these microfluidic systems continue to evolve and grow in their utility, so will our insight into the fundamental properties and functions of the microvasculature in sustaining tissue health and in contributing to certain disease conditions [154].

A number of opportunities remain in fully optimizing the design of microfluidic platforms to more faithfully recapitulate the microcirculation. One major challenge is that many vascular channels that form in fluidics devices rarely remain at a diameter size that would be considered on the order of capillaries. Specifically, microvessel diameters typically fall within a range of $3-10 \mu \mathrm{m}$, while many microfluidic platforms operate at diameters larger than $10 \mu \mathrm{m}$. In addition, the materials used in generating these systems may limit the ability to incorporate multiple cell types along the microvessel wall. These materials may also affect the synthesis and deposition of ECM proteins, causing further divergence from vBM compositions found in vivo. Because the vBM derived from pericytes and endothelial cells provide a level of structural and mechanical integrity to the microvessel wall, the cell-biomaterial interface becomes a very important parameter to optimize for strengthening confidence in the observations made. This challenge is also relevant in use of these models to understand how fluid inside the vessel exerts specific forces on the vessel wall beyond the shear stresses that impinge upon the endothelium. Specifically, intraluminal "blood" pressure creates circumferential, radial, and axial wall stresses that are counteracted by biological elements in vivo (i.e. cell stress fibers, ECM components, etc.) (Fig. 2a). In microfluidic devices, these forces might be absorbed by synthetic elements in the system and may therefore prevent endothelial cells and pericytes from adapting physiologically to their mechanical environment.

Recent technological advances in both biomaterials and micro-fabrication techniques including bio-printing capabilities are pushing microfluidic systems into an era of enormous potential for modeling the microcirculation. These bioengineered models will expand our understanding of microvascular biology and how to use insight into these "first principles" to guide development of clinically relevant therapies for vascular-related pathologies. These rapidly advancing bioengineered microvasculature systems are not without critical limitations however. For example, challenges remain in adequately accounting for key differences and potential heterogeneities in the diffusion barrier of vessels relative to the cell types that may be close spatial proximity to the vessel wall [155]. Work from Dr. Roger Kamm and colleagues for instance demonstrated that biochemical crosstalk with macrophages influences endothelial barrier function and impacts tumor cell migration dynamics, among other modulation of the vessel barrier [155]. Incorporating vascular pericytes into these novel bioengineered microvessel platforms will be an important component of overcoming current technological hurdles, which will usher in new insights into the complex biology of the microcirculation that is relevant to tissue engineering applications [6], cancer immunotherapy [156, 157], and beyond.

\section{Computational modeling of microvascular Pericytes}

As our appreciation of biological complexity grows with each new discovery, we must also develop tools and methods to integrate those insights into working models that will (i) enhance our understanding of biological systems at all levels, and (ii) generate new hypotheses to test, yielding new discoveries and model refinement. Computational modeling represents a primary example of such a tool that facilitates synthesis of data sets and observations from a wide range of experimental systems [158]. In addition, properly validated computational models can offer a means for exploring specific perturbations that might be beyond what is feasibility in experimental models. The field of vascular biology has benefited from the application of in silico models to a variety of questions focused on the microcirculation. Computer simulations have been developed for sprouting angiogenesis [159-161] (Fig. 2b), systemic and localized growth factor kinetics $[162,163]$, and microvascular biomechanics [164], as well as for oxygen/nutrient exchange within tissue microcirculation $[101,165]$ and drug delivery across the microvessel wall [166]. Endothelial cells have been the focus for many of these models, but as we learn more about how pericytes influence endothelial cell function (and vice versa), it will be important to build upon previous models and incorporate the pericyte compartment into the parameter space, rule sets, and governing algorithms.

\section{Computational models of angiogenesis}

Angiogenic remodeling is a highly dynamic process involving coordination of numerous cellular behaviors through complex and interconnected signaling networks [161]. Experimental observation of these events yields data sets from various levels including transcriptional, molecular, and cellular. This information guides model construction with regard to rule sets for specific cell activities such as endothelial cell migration or filopodial extensions, as seen in agent-based modeling (ABM) approaches [159, 164, 167]. Multi-scale models couple these actions to underlying molecular pathways and kinetic modeling where each molecular species is accounted 
for by specific equations [158] (Fig. 2b). This type of modeling has been used to address the complexities of Vascular Endothelial Growth Factor-A (VEGF-A) signaling and crosstalk with the Delta-like 4 (Dll4)-Notch pathway during angiogenic sprouting [16, 168-170], among other signaling mechanisms. Recently, Ubezio et al. utilized complementary experimental and computational models to demonstrate the importance of dynamic fluctuations in endothelial Dll4 levels for normal blood vessel growth [168]. It is becoming increasingly apparent that vascular pericytes are present on, and track very closely along, sprouting endothelial cells [83], suggesting that these and other similar models might provide additional insight into angiogenesis by considering the potential involvement of pericytes.

The various roles that pericytes may play during angiogenesis are still being elucidated. Sprouting endothelial cells are known to secrete PDGF-BB [171], to which pericytes respond by maintaining close proximity to these outwardly migrating cells. Because of their proximate location to endothelial sprouts, pericytes are likely capable of directly or indirectly influencing Notch signals exchanged by endothelial "tip" and "stalk" cells [83]. Pericytes may also provide feedback regulation of angiogenic sprouting by a variety of other mechanisms. For instance, pericytes secrete Angiopoietin-1 (Angpt1) that binds Tie 2 on the endothelium to stabilize microvessels, attenuate vascular remodeling and permeability, and induce quiescence [172]. Pericytes have also been proposed to regulate VEGF-A signaling via synthesis of VEGF-A receptors [173, 174], but this role may be context-dependent as observations from a range of models suggest that pericytes produce little, if any, of the known VEGF receptors [43-46, 175-179]. In addition to pro- and anti-angiogenic signaling regulation, pericytes also make unique contributions to the $\mathrm{ECM}$ at the pericyte-endothelial cell interface as well as surrounding developing vessels, i.e. the vBM [43, 90]. These ECM components such as fibronectin, collagens and laminins provide structural stability for nascent vessels [126], and are also known to retain and present growth factors that modulate angiogenesis [30, 31, 180]. Our collective understanding of these and emerging modes of pericyte involvement in angiogenesis is still expanding, and as it does, it will be useful to integrate these molecular mechanisms and cellular behaviors into new and existing computational models of angiogenesis to gain even more insight into how endothelial cells and pericytes coordinate the formation of new blood vessels.

\section{Mathematical approaches to growth factor kinetics}

In contrast to the models described above that capture the localized growth factor effects, in silico models have also been developed to describe the systemic distribution and effects of soluble growth factors and their receptors. Kinetics of the VEGF-A pathway for example have been implemented in computational models, giving predications for VEGF-A concentrations in the blood as well as for levels of soluble VEGF-A receptors such as soluble Flt-1 (sFlt-1/sVEGFR1) [162, 163]. These models require a precise accounting of all sources of both VEGF-A ligands as well as VEGF-A receptors. For this reason, studies implicating pericytes as potential sources of VEGF-A ligand and/or its receptors [173, 174] are important to validate and further establish the extent to which these potential pericyte sources of VEGF-A ligands and receptors are functionally relevant [57]. Similar analysis is likely warranted for other signaling pathways related to pericyte function, such as the PDGF-BB pathway. Soluble isoforms of PDGFR $\beta$ have been described in several contexts $[137,181]$ including the developing brain [182], which may be able to diffuse into the systemic circulation and exert effects more broadly. Computational platforms that can simulate both local and systemic PDGF-PDGFR $\beta$ dynamics will be essential for understanding how pericytes might respond to both near-field and circulating cues.

\section{Microvascular biomechanics}

Studies exploring the effects of biomechanical cues on the microcirculation have largely focused on shear stresses from blood flowing along the apical surface of the endothelium $[8,131-135]$. As mentioned above, intraluminal blood pressure also exerts forces on the microvessel wall, namely circumferential, radial, and axial wall stresses [135]. Pericytes within the vessel wall certainly experience these mechanical inputs and likely respond in specific ways such as contracting [183] or perhaps increasing ECM deposition into the vBM. Confirmation that pericytes contribute to vessel wall compliance in response to intraluminal pressure was provided recently by studies in which pericytes were selectively ablated $[19,184]$. In microvessel regions void of pericyte investment, capillary diameters passively increased until a pericyte extension restored coverage in these areas [184]. These observations support the idea that pericytes contribute to the mechanical properties and structural integrity of the microvessel wall, and should therefore be included in computational models focused on capillary biomechanics during both angiogenic remodeling and microvascular homeostasis.

\section{Microcirculation transport modeling}

Models of oxygen diffusion and nutrient exchange create another window into one of the most important functions of the microcirculation [185]. Measuring oxygen diffusion and nutrient/waste exchange in vivo poses numerous technical challenges, some of which are being 
addressed by recent methodological advances [35, 101, 186]. Complementing the development of experimental approaches, computational methods have been used to predict solute exchange throughout microvascular networks [187]. These approaches are essential to understanding how physiological and pathological changes in the microvessel wall, including in the pericyte compartment and with their associated ECM, can affect distribution of nutrients and oxygen within a tissue. Sweeney et al. recently developed a mathematical model that also captured pericyte contributions to cerebral blood flow regulation by acting primarily as signaling conduits to activate vSMCs upstream [101]. Dynamic imaging of the mouse cortical microvasculature provided corresponding experimental observations in support of this model, demonstrating the utility of combining high-power imaging modalities with rigorous computational methods. Similar approaches focused on drug delivery applications can provide insight into how these vehicles might be designed for optimal transfer within the microcirculation [151]. Given the importance of pericyte contributions to the microvessel wall, and perhaps in regulating endothelial uptake and transcytosis [12], it will be important to integrate pericytes into these models to better predict how certain drugs cross from the bloodstream into surrounding tissues.

\section{Conclusions}

As transcriptional profiling and high-resolution imaging technologies continue to advance at an exciting pace, so too will our understanding of pericytes and their important contributions to the microvasculature. New insights will allow us to effectively incorporate pericytes into in vitro and in silico bioengineered constructs and more faithfully replicate essential features of in vivo microvascular networks. These novel platforms will facilitate testing new therapeutic approaches to enhancing microvascular growth in clinically relevant scenarios. They will also strengthen our ability to screen new and existing drug compounds for intentional and unexpected effects on the microcirculation [188], and specifically on microvascular pericytes [149]. For example, drugs given to myocardial infarction or stroke patients to induce vasodilation and restore tissue perfusion might actually have deleterious effects on pericytes, directly or indirectly (e.g. reperfusion injury), and contribute to "no reflow" within capillary networks [93, 96, 189, 190]. Cell-based therapies harnessing iPSC technology and the like can also be evaluated in these pre-clinical models, accelerating the translation of basic discoveries into medical solutions. It is therefore imperative to continue sharpening our knowledge of pericytes, uncovering their potential as drug targets as well as increasing the fidelity of bioengineered microvascular constructs.

\section{Abbreviations}

ABM: Agent-Based Model; CNS: Central Nervous System; Col-I: Type I Collagen; Col-IV: Type IV Collagen; DII4: Delta-Like 4; ECM: Extracellular Matrix; ESC: Embryonic Stem Cell; HUVEC: Human Umbilical Vein Endothelial Cell; IPL: Idiopathic Pulmonary Fibrosis; iPSC: Induced Pluripotent Stem Cell; MSC: Mesenchymal Stem Cell; NG2: Neural Glial Antigen-2;

OPC: Oligodendrocyte Precursor Cell; PDGF-BB: Platelet-Derived Growth Factor-BB; PDGFR $\beta$ : Platelet-Derived Growth Factor Receptor- $\beta$;

SEM: Scanning Electron Microscopy; vBM: Vascular Basement Membrane; VECadherin: Vascular Endothelial Cadherin; VEGF-A: Vascular Endothelial Growth Factor-A; VEGFR1: Vascular Endothelial Growth Factor Receptor-1; VHL: Von Hippel-Lindau; vSMC: Vascular Smooth Muscle Cell;; ZO-1: Zona Occludins-1; aSMA: a-Smooth Muscle Actin

\section{Acknowledgements}

We thank Chappell Lab members for critical and extensive discussions of published data and important concepts in the field.

\section{Funding}

This review was supported by the National Institutes of Health (ROOHL105779 and R56HL133826 to JCC) and the National Science Foundation (CAREER Award, Proposal \# 1752339 to JCC).

Availability of data and materials

Not applicable.

\section{Authors' contributions}

$\mathrm{HZ}$ collected references, formulated a detailed outline, and edited the review. JCC wrote and edited the manuscript. Both authors read and approved the final manuscript.

\section{Ethics approval and consent to participate}

Not applicable.

Consent for publication

Not applicable.

\section{Competing interests}

The authors declare that they have no competing interests.

\section{Publisher's Note}

Springer Nature remains neutral with regard to jurisdictional claims in published maps and institutional affiliations.

\section{Author details}

${ }^{1}$ Center for Heart and Reparative Medicine, Fralin Biomedical Research Institute, 2 Riverside Circle, Roanoke, VA 24016, USA. ²Department of Biomedical Engineering and Mechanics, Virginia Polytechnic State Institute and State University, Blacksburg, VA 24061, USA. ${ }^{3}$ Department of Basic Science Education, Virginia Tech Carilion School of Medicine, Roanoke, VA 24016, USA.

Received: 3 December 2018 Accepted: 15 March 2019

Published online: 29 March 2019

\section{References}

1. Potente M, Gerhardt H, Carmeliet P. Basic and therapeutic aspects of angiogenesis. Cell. 2011;146(6):873-87.

2. Carmeliet P. Angiogenesis in life, disease and medicine. Nature. 2005; 438(7070):932-6.

3. Majesky MW, Dong XR, Regan JN, Hoglund VJ. Vascular smooth muscle progenitor cells: building and repairing blood vessels. Circ Res. 2011;108(3): 365-77.

4. Larrivee B, Freitas C, Suchting S, Brunet I, Eichmann A. Guidance of vascular development: lessons from the nervous system. Circ Res. 2009;104(4):428-41.

5. Leslie-Barbick JE, Saik JE, Gould DJ, Dickinson ME, West JL. The promotion of microvasculature formation in poly(ethylene glycol) diacrylate hydrogels by an immobilized VEGF-mimetic peptide. Biomaterials. 2011;32:5782-9.

6. Campagnolo P, Gormley AJ, Chow LW, Guex AG, Parmar PA, Puetzer JL, et al. Pericyte seeded dual peptide scaffold with improved Endothelialization for vascular graft tissue engineering. Adv Healthc Mater. 2016;5(23):3046-55. 
7. von Bornstadt D, Wang H, Paulsen MJ, Goldstone AB, Eskandari A, Thakore A, et al. Rapid self-assembly of bioengineered cardiovascular bypass grafts from scaffold-stabilized, tubular bilevel cell sheets. Circulation. 2018;138(19): 2130-44.

8. La A, Tranquillo RT. Shear conditioning of adipose stem cells for reduced platelet binding to engineered vascular grafts. Tissue Eng Part A. 2018; 24(15-16):1242-50

9. Gastfriend BD, Palecek SP, Shusta EV. Modeling the blood-brain barrier: beyond the endothelial cells. Curr Opin Biomed Eng. 2018;5:6-12.

10. Jamieson JJ, Searson PC, Gerecht S. Engineering the human blood-brain barrier in vitro. J Biol Eng. 2017;11:37.

11. Zhao Z, Nelson AR, Betsholtz C, Zlokovic BV. Establishment and dysfunction of the blood-brain barrier. Cell. 2015;163(5):1064-78.

12. Armulik A, Genove G, Mae M, Nisancioglu MH, Wallgard E, Niaudet C, et al. Pericytes regulate the blood-brain barrier. Nature. 2010;468(7323):557-61.

13. Daneman R, Zhou L, Kebede AA, Barres BA. Pericytes are required for bloodbrain barrier integrity during embryogenesis. Nature. 2010;468(7323):562-6.

14. Balabanov R, Dore-Duffy P. Role of the CNS microvascular pericyte in the blood-brain barrier. J Neurosci Res. 1998;53(6):637-44.

15. Barry DM, Xu K, Meadows SM, Zheng Y, Norden PR, Davis GE, et al. Cdc42 is required for cytoskeletal support of endothelial cell adhesion during blood vessel formation in mice. Development. 2015;142(17):3058-70.

16. Bentley K, Franco CA, Philippides A, Blanco R, Dierkes M, Gebala V, et al. The role of differential VE-cadherin dynamics in cell rearrangement during angiogenesis. Nat Cell Biol. 2014;16(4):309-21.

17. Wessel F, Winderlich M, Holm M, Frye M, Rivera-Galdos R, Vockel M, et al. Leukocyte extravasation and vascular permeability are each controlled in vivo by different tyrosine residues of VE-cadherin. Nat Immunol. 2014;15(3): 223-30.

18. Winderlich M, Keller L, Cagna G, Broermann A, Kamenyeva O, Kiefer F, et al. VE-PTP controls blood vessel development by balancing Tie-2 activity. J Cell Biol. 2009;185(4):657-71.

19. Berthiaume AA, Hartmann DA, Majesky MW, Bhat NR, Shih AY. Pericyte structural remodeling in cerebrovascular health and homeostasis. Front Aging Neurosci. 2018;10:210.

20. Trost A, Lange S, Schroedl F, Bruckner D, Motloch KA, Bogner B, et al. Brain and retinal pericytes: origin, function and role. Front Cell Neurosci. 2016;10:20.

21. Hurtado-Alvarado G, Cabanas-Morales AM, Gomez-Gonzalez B. Pericytes: brain-immune interface modulators. Front Integr Neurosci. 2014;7:80.

22. Sims DE. The pericyte--a review. Tissue Cell. 1986;18(2):153-74.

23. Rouget C. Memoire sur le developpement, la structure et les proprietes physiologiques des capillaires sanguins. Archives Physiol Normale Pathol. 1873;5:603-61.

24. Eberth CJ. Handbuch der-Lehre von den Gewebwn des Menschen und der Tiere, vol. 1. Leipzig: Engelmann; 1871

25. Armulik A, Genove G, Betsholtz C. Pericytes: developmental, physiological, and pathological perspectives, problems, and promises. Dev Cell. 2011;21(2):193-215.

26. Alarcon-Martinez L, Yilmaz-Ozcan S, Yemisci M, Schallek J, Kilic K, Can A, et al. Capillary pericytes express alpha-smooth muscle actin, which requires prevention of filamentous-actin depolymerization for detection. Elife. 2018;7. https://doi.org/10.7554/eLife.34861.

27. Trost A, Schroedl F, Lange S, Rivera FJ, Tempfer H, Korntner S, et al. Neural crest origin of retinal and choroidal pericytes. Invest Ophthalmol Vis Sci. 2013;54(13):7910-21.

28. Korn J, Christ B, Kurz H. Neuroectodermal origin of brain pericytes and vascular smooth muscle cells. J Comp Neurol. 2002;442(1):78-88.

29. Blocki A, Beyer S, Jung F, Raghunath $M$. The controversial origin of pericytes during angiogenesis - implications for cell-based therapeutic angiogenesis and cell-based therapies. Clin Hemorheol Microcirc. 2018;69(1-2):215-32.

30. Abramsson A, Kurup S, Busse M, Yamada S, Lindblom P, Schallmeiner E, et al. Defective N-sulfation of heparan sulfate proteoglycans limits PDGF-BB binding and pericyte recruitment in vascular development. Genes Dev. 2007;21(3):316-31

31. Lindblom $P$, Gerhardt $H$, Liebner $S$, Abramsson A, Enge M, Hellstrom M, et al. Endothelial PDGF-B retention is required for proper investment of pericytes in the microvessel wall. Genes Dev. 2003:17(15):1835-40.

32. Abramsson A, Lindblom P, Betsholtz C. Endothelial and nonendothelial sources of PDGF-B regulate pericyte recruitment and influence vascular pattern formation in tumors. J Clin Invest. 2003;112(8):1142-51.

33. Hellstrom M, Kalen M, Lindahl P, Abramsson A, Betsholtz C. Role of PDGF-B and PDGFR-beta in recruitment of vascular smooth muscle cells and pericytes during embryonic blood vessel formation in the mouse. Development. 1999;126(14) 3047-55.

34. Lindahl P, Johansson BR, Leveen P, Betsholtz C. Pericyte loss and microaneurysm formation in PDGF-B-deficient mice. Science. 1997: 277(5323):242-5.

35. Kisler K, Nelson AR, Rege SV, Ramanathan A, Wang Y, Ahuja A, Lazic D, Tsai PS, Zhao Z, Zhou Y, Boas DA, Sakadžić S, Zlokovic BV. Pericyte degeneration leads to neurovascular uncoupling and limits oxygen supply to brain. Nat Neurosci. 2017;20(3):406-16. https:/doi.org/10.1038/nn.4489 Epub 2017 Jan 30

36. Bell RD, Winkler EA, Sagare AP, Singh I, LaRue B, Deane R, et al. Pericytes control key neurovascular functions and neuronal phenotype in the adult brain and during brain aging. Neuron. 2010;68(3):409-27.

37. Jin S, Hansson EM, Tikka S, Lanner F, Sahlgren C, Farnebo F, et al. Notch signaling regulates platelet-derived growth factor receptor-beta expression in vascular smooth muscle cells. Circ Res. 2008:102(12):1483-91.

38. Cuervo H, Pereira B, Nadeem T, Lin M, Lee F, Kitajewski J, et al. PDGFRbeta-P2ACreER(T2) mice: a genetic tool to target pericytes in angiogenesis. Angiogenesis. 2017;20(4):655-62

39. Trotter J, Karram K, Nishiyama A. NG2 cells: properties, progeny and origin. Brain Res Rev. 2010;63(1-2):72-82.

40. Zhu X, Bergles DE, Nishiyama A. NG2 cells generate both oligodendrocytes and gray matter astrocytes. Development. 2008;135(1):145-57.

41. Murfee WL, Rehorn MR, Peirce SM, Skalak TC. Perivascular cells along venules upregulate NG2 expression during microvascular remodeling. Microcirculation. 2006;13(3):261-73.

42. Vanlandewijck M, He L, Mae MA, Andrae J, Ando K, Del Gaudio F, et al. A molecular atlas of cell types and zonation in the brain vasculature. Nature 2018:554(7693):475-80.

43. He L, Vanlandewijck M, Raschperger E, Andaloussi Mae M, Jung B, Lebouvier T, et al. Analysis of the brain mural cell transcriptome. Sci Rep. 2016:6:35108

44. Hrvatin S, Hochbaum DR, Nagy MA, Cicconet M, Robertson K, Cheadle L, et al. Single-cell analysis of experience-dependent transcriptomic states in the mouse visual cortex. Nat Neurosci. 2018;21(1):120-9.

45. Zeisel A, Hochgerner $H$, Lonnerberg $P$, Johnsson A, Memic F, van der Zwan J, et al. Molecular architecture of the mouse nervous system. Cell. 2018;174(4): 999-1014 e22.

46. Daneman R, Zhou L, Agalliu D, Cahoy JD, Kaushal A, Barres BA. The mouse blood-brain barrier transcriptome: a new resource for understanding the development and function of brain endothelial cells. PLoS One. 2010;5(10): e13741.

47. Zhang Y, Chen K, Sloan SA, Bennett ML, Scholze AR, O'Keeffe S, et al. An RNA-sequencing transcriptome and splicing database of glia, neurons, and vascular cells of the cerebral cortex. J Neurosci. 2014;34(36):11929-47.

48. He L, Vanlandewijck M, Mae MA, Andrae J, Ando K, Del Gaudio F, et al. Single-cell RNA sequencing of mouse brain and lung vascular and vessel-associated cell types. Sci Data. 2018:5:180160.

49. Jung B, Arnold TD, Raschperger E, Gaengel K, Betsholtz C. Visualization of vascular mural cells in developing brain using genetically labeled transgenic reporter mice. J Cereb Blood Flow Metab. 2018:38(3):456-68.

50. Zhao H, Darden J, Chappell JC. Establishment and Characterization of an Embryonic Pericyte Cell Line. Microcirculation. 2018:e12461. https://doi.org/10, $1111 /$ micc.12461

51. Grant RI, Hartmann DA, Underly RG, Berthiaume AA, Bhat NR, Shih AY. Organizational hierarchy and structural diversity of microvascular pericytes in adult mouse cortex. J Cereb Blood Flow Metab. 2017. https://doi.org/10. $1177 / 0271678 \times 17732229$

52. Rungta RL, Chaigneau E, Osmanski BF, Charpak S. Vascular compartmentalization of functional hyperemia from the synapse to the pia. Neuron. 2018;99(2):362-75 e4.

53. Birbrair A, Zhang T, Files DC, Mannava S, Smith T, Wang ZM, et al. Type-1 pericytes accumulate after tissue injury and produce collagen in an organdependent manner. Stem Cell Res Ther. 2014:5(6):122.

54. Birbrair A, Zhang T, Wang ZM, Messi ML, Olson JD, Mintz A, et al. Type-2 pericytes participate in normal and tumoral angiogenesis. Am J Physiol Cell Physiol. 2014;307(1):C25-38.

55. Egginton S, Hudlicka O, Brown MD, Graciotti L, Granata AL. In vivo pericyteendothelial cell interaction during angiogenesis in adult cardiac and skeletal muscle. Microvasc Res. 1996:51(2):213-28.

56. Hammer S, Monavarfeshani A, Lemon T, Su J, Fox MA. Multiple retinal axons converge onto relay cells in the adult mouse thalamus. Cell Rep. 2015; 12(10):1575-83. 
57. Evensen L, Micklem DR, Blois A, Berge SV, Aarsaether N, Littlewood-Evans A, et al. Mural cell associated VEGF is required for organotypic vessel formation. PLoS One. 2009;4(6):e5798.

58. Greenberg Jl, Shields DJ, Barillas SG, Acevedo LM, Murphy E, Huang J, et al. A role for VEGF as a negative regulator of pericyte function and vessel maturation. Nature. 2008:456(7223):809-13.

59. Liu H, Zhang W, Lilly B. Evaluation of Notch3 deficiency in diabetes-induced Pericyte loss in the retina. J Vasc Res. 2018;55(5):308-18.

60. Volz KS, Jacobs AH, Chen HI, Poduri A, McKay AS, Riordan DP, et al. Pericytes are progenitors for coronary artery smooth muscle. Elife. 2015;4. https://doi. org/10.7554/eLife.10036.

61. High FA, Lu MM, Pear WS, Loomes KM, Kaestner KH, Epstein JA. Endothelial expression of the notch ligand Jagged1 is required for vascular smooth muscle development. Proc Natl Acad Sci U S A. 2008;105(6):1955-9.

62. Kofler NM, Cuervo H, Uh MK, Murtomaki A, Kitajewski J. Combined deficiency of Notch1 and Notch3 causes pericyte dysfunction, models CADASIL, and results in arteriovenous malformations. Sci Rep. 2015;5:16449.

63. Liu H, Kennard S, Lilly B. NOTCH3 expression is induced in mural cells through an autoregulatory loop that requires endothelial-expressed JAGGED1. Circ Res. 2009;104(4):466-75.

64. Domenga $\mathrm{V}$, Fardoux $\mathrm{P}$, Lacombe $\mathrm{P}$, Monet M, Maciazek J, Krebs LT, et al. Notch3 is required for arterial identity and maturation of vascular smooth muscle cells. Genes Dev. 2004;18(22):2730-5.

65. Birbrair A, Zhang T, Wang ZM, Messi ML, Mintz A, Delbono O. Pericytes at the intersection between tissue regeneration and pathology. Clin Sci (Lond). 2015;128(2):81-93.

66. Birbrair A, Zhang T, Wang ZM, Messi ML, Enikolopov GN, Mintz A, et al. Role of pericytes in skeletal muscle regeneration and fat accumulation. Stem Cells Dev. 2013;22(16):2298-314.

67. Crisan M, Yap S, Casteilla L, Chen CW, Corselli M, Park TS, et al. A perivascular origin for mesenchymal stem cells in multiple human organs. Cell Stem Cell. 2008;3(3):301-13.

68. Caplan Al. All MSCs are pericytes? Cell Stem Cell. 2008;3(3):229-30.

69. Caplan Al. Adult mesenchymal stem cells for tissue engineering versus regenerative medicine. J Cell Physiol. 2007;213(2):341-7.

70. Diaz-Flores L, Gutierrez R, Madrid JF, Varela H, Valladares F, Acosta E, et al. Pericytes. Morphofunction, interactions and pathology in a quiescent and activated mesenchymal cell niche. Histol Histopathol. 2009:24(7):909-69.

71. Davidoff MS, Middendorff R, Enikolopov G, Riethmacher D, Holstein AF, Muller D. Progenitor cells of the testosterone-producing Leydig cells revealed. J Cell Biol. 2004;167(5):935-44

72. Crisan M, Deasy B, Gavina M, Zheng B, Huard J, Lazzari L, et al. Purification and long-term culture of multipotent progenitor cells affiliated with the walls of human blood vessels: myoendothelial cells and pericytes. Methods Cell Biol. 2008:86:295-309.

73. Feng J, Mantesso A, De Bari C, Nishiyama A, Sharpe PT. Dual origin of mesenchymal stem cells contributing to organ growth and repair. Proc Natl Acad Sci U S A. 2011;108(16):6503-8.

74. Olson LE, Soriano P. PDGFRbeta signaling regulates mural cell plasticity and inhibits fat development. Dev Cell. 2011;20(6):815-26.

75. Tang W, Zeve D, Suh JM, Bosnakovski D, Kyba M, Hammer RE, et al. White fat progenitor cells reside in the adipose vasculature. Science. 2008; 322(5901):583-6.

76. Dore-Duffy P, Katychev A, Wang X, Van Buren E. CNS microvascular pericytes exhibit multipotential stem cell activity. J Cereb Blood Flow Metab. 2006;26(5):613-24.

77. Dellavalle A, Sampaolesi M, Tonlorenzi R, Tagliafico E, Sacchetti B, Perani L, et al. Pericytes of human skeletal muscle are myogenic precursors distinct from satellite cells. Nat Cell Biol. 2007;9(3):255-67.

78. Paquet-Fifield S, Schluter H, Li A, Aitken T, Gangatirkar P, Blashki D, et al. A role for pericytes as microenvironmental regulators of human skin tissue regeneration. J Clin Invest. 2009;119(9):2795-806.

79. Yianni V, Sharpe PT. Molecular programming of perivascular stem cell precursors. Stem Cells. 2018. https://doi.org/10.1002/stem.2895.

80. Guimaraes-Camboa N, Cattaneo P, Sun Y, Moore-Morris T, Gu Y, Dalton ND, et al. Pericytes of multiple organs do not behave as mesenchymal stem cells in vivo. Cell Stem Cell. 2017;20(3):345-59 e5.

81. Ozerdem U, Stallcup WB. Early contribution of pericytes to angiogenic sprouting and tube formation. Angiogenesis. 2003;6(3):241-9.

82. Chang WG, Andrejecsk JW, Kluger MS, Saltzman WM, Pober JS. Pericytes modulate endothelial sprouting. Cardiovasc Res. 2013;100(3):492-500.
83. Walpole J, Gabhann FM, Peirce SM, Chappell JC. Agent-based Computational Model of Retinal Angiogenesis Simulates Microvascular Network Morphology as a Function of Pericyte Coverage. Microcirculation. 2017. https://doi.org/10.1111/ micc.12393.

84. Eglinger J, Karsjens H, Lammert E. Quantitative assessment of angiogenesis and pericyte coverage in human cell-derived vascular sprouts. Inflamm Regen. 2017;37(1):2.

85. Seynhaeve ALB, Oostinga D, van Haperen R, Eilken HM, Adams S, Adams $\mathrm{RH}$, et al. Spatiotemporal endothelial cell - pericyte association in tumors as shown by high resolution 4D intravital imaging. Sci Rep. 2018;8(1):9596.

86. Jakobsson L, Kreuger J, Claesson-Welsh L. Building blood vessels--stem cell models in vascular biology. J Cell Biol. 2007;177(5):751-5.

87. Simonavicius N, Ashenden M, van Weverwijk A, Lax S, Huso DL, Buckley CD, et al. Pericytes promote selective vessel regression to regulate vascular patterning. Blood. 2012:120(7):1516-27.

88. Stratman AN, Malotte KM, Mahan RD, Davis MJ, Davis GE. Pericyte recruitment during vasculogenic tube assembly stimulates endothelial basement membrane matrix formation. Blood. 2009;114(24):5091-101.

89. Hellstrom M, Gerhardt H, Kalen M, Li X, Eriksson U, Wolburg H, et al. Lack of pericytes leads to endothelial hyperplasia and abnormal vascular morphogenesis. J Cell Biol. 2001:153(3):543-53.

90. Sava P, Cook 1O, Mahal RS, Gonzalez AL. Human microvascular pericyte basement membrane remodeling regulates neutrophil recruitment. Microcirculation. 2015;22(1):54-67.

91. Courtoy PJ, Boyles J. Fibronectin in the microvasculature: localization in the pericyte-endothelial interstitium. J Ultrastruct Res. 1983;83(3):258-73.

92. Mandarino $L$, Sundarraj N, Finlayson J, Hassell HR. Regulation of fibronectin and laminin synthesis by retinal capillary endothelial cells and pericytes in vitro. Exp Eye Res. 1993;57(5):609-21.

93. O'Farrell FM, Mastitskaya S, Hammond-Haley M, Freitas F, Wah WR, Attwell D. Capillary pericytes mediate coronary no-reflow after myocardial ischaemia. Elife. 2017;6. https://doi.org/10.7554/eLife.29280.

94. Hall CN, Reynell C, Gesslein B, Hamilton NB, Mishra A, Sutherland BA, et al. Capillary pericytes regulate cerebral blood flow in health and disease. Nature. 2014;508(7494):55-60.

95. Mishra A, O'Farrell FM, Reynell C, Hamilton NB, Hall CN, Attwell D. Imaging pericytes and capillary diameter in brain slices and isolated retinae. Nat Protoc. 2014:9(2):323-36.

96. O'Farrell FM, Attwell D. A role for pericytes in coronary no-reflow. Nat Rev Cardiol. 2014;11(7):427-32

97. Hamilton NB, Attwell D, Hall CN. Pericyte-mediated regulation of capillary diameter: a component of neurovascular coupling in health and disease. Front Neuroenerg. 2010;2. https://doi.org/10.3389/fnene.2010.00005.

98. Peppiatt CM, Howarth C, Mobbs P, Attwell D. Bidirectional control of CNS capillary diameter by pericytes. Nature. 2006:443(7112):700-4.

99. Hillman EM. Coupling mechanism and significance of the BOLD signal: a status report. Annu Rev Neurosci. 2014:37:161-81.

100. Fernandez-Klett F, Offenhauser N, Dirnagl U, Priller J, Lindauer U. Pericytes in capillaries are contractile in vivo, but arterioles mediate functional hyperemia in the mouse brain. Proc Natl Acad Sci U S A. 2010;107(51):22290-5.

101. Sweeney PW, Walker-Samuel S, Shipley RJ. Insights into cerebral haemodynamics and oxygenation utilising in vivo mural cell imaging and mathematical modelling. Sci Rep. 2018;8(1):1373.

102. Hill RA, Tong L, Yuan P, Murikinati S, Gupta S, Grutzendler J. Regional blood flow in the Normal and ischemic brain is controlled by arteriolar smooth muscle cell contractility and not by capillary Pericytes. Neuron. 2015;87(1):95-110.

103. Antonetti DA, Klein R, Gardner TW. Diabetic retinopathy. N Engl J Med. 2012;366(13):1227-39.

104. Valdez CN, Arboleda-Velasquez JF, Amarnani DS, Kim LA, D'Amore PA. Retinal microangiopathy in a mouse model of inducible mural cell loss. Am J Pathol. 2014;184(10):2618-26.

105. Mendel TA, Clabough EB, Kao DS, Demidova-Rice TN, Durham JT, Zotter BC, et al. Pericytes derived from adipose-derived stem cells protect against retinal vasculopathy. PLoS One. 2013;8(5):e65691.

106. Geraldes $P$, Hiraoka-Yamamoto J, Matsumoto M, Clermont A, Leitges M, Marette A, et al. Activation of PKC-delta and SHP-1 by hyperglycemia causes vascular cell apoptosis and diabetic retinopathy. Nat Med. 2009;15(11):1298-306.

107. Pfister F, Feng Y, Vom Hagen F, Hoffmann S, Molema G, Hillebrands JL, et al. Pericyte migration: a novel mechanism of pericyte loss in experimental diabetic retinopathy. Diabetes. 2008;57(9):2495-502. 
108. Sava P, Ramanathan A, Dobronyi A, Peng X, Sun H, Ledesma-Mendoza A, et al. Human pericytes adopt myofibroblast properties in the microenvironment of the IPF lung. JCI Insight. 2017;2(24). https://doi.org/10. 1172/jci.insight.96352.

109. Stefanska A, Eng D, Kaverina N, Duffield JS, Pippin JW, Rabinovitch P, et al. Interstitial pericytes decrease in aged mouse kidneys. Aging (Albany NY). 2015; 7(6):370-82.

110. Lin SL, Kisseleva T, Brenner DA, Duffield JS. Pericytes and perivascular fibroblasts are the primary source of collagen-producing cells in obstructive fibrosis of the kidney. Am J Pathol. 2008;173(6):1617-27.

111. Rock JR, Barkauskas CE, Cronce MJ, Xue Y, Harris JR, Liang J, et al. Multiple stromal populations contribute to pulmonary fibrosis without evidence for epithelial to mesenchymal transition. Proc Natl Acad Sci U S A. 2011;108(52): E1475-83.

112. Suzuma K, Naruse K, Suzuma I, Takahara N, Ueki K, Aiello LP, et al. Vascular endothelial growth factor induces expression of connective tissue growth factor via KDR, Flt1, and phosphatidylinositol 3-kinase-akt-dependent pathways in retinal vascular cells. J Biol Chem. 2000;275(52):40725-31.

113. Joutel A, Faraci FM. Cerebral small vessel disease: insights and opportunities from mouse models of collagen IV-related small vessel disease and cerebral autosomal dominant arteriopathy with subcortical infarcts and leukoencephalopathy. Stroke. 2014;45(4):1215-21.

114. Ratelade J, Mezouar N, Domenga-Denier V, Rochey A, Plaisier E, Joutel A. Severity of arterial defects in the retina correlates with the burden of intracerebral haemorrhage in COL4A1-related stroke. J Pathol. 2018;244(4):408-20.

115. Arreola A, Payne LB, Julian MH, de Cubas AA, Daniels AB, Taylor S, et al. Von Hippel-Lindau mutations disrupt vascular patterning and maturation via Notch. JCI Insight. 2018;3(4). https://doi.org/10.1172/jci.insight.92193.

116. Li Y, Lucas-Osma AM, Black S, Bandet MV, Stephens MJ, Vavrek R, et al. Pericytes impair capillary blood flow and motor function after chronic spinal cord injury. Nat Med. 2017;23(6):733-41.

117. Winkler EA, Bell RD, Zlokovic BV. Central nervous system pericytes in health and disease. Nat Neurosci. 2011;14(11):1398-405.

118. Kelly-Goss MR, Sweat RS, Stapor PC, Peirce SM, Murfee WL. Targeting pericytes for angiogenic therapies. Microcirculation. 2014;21(4):345-57.

119. Armulik A, Abramsson A, Betsholtz C. Endothelial/pericyte interactions. Circ Res. 2005;97(6):512-23.

120. Gerhardt H, Betsholtz C. Endothelial-pericyte interactions in angiogenesis. Cell Tissue Res. 2003;314(1):15-23.

121. Chappell JC, Cluceru JG, Nesmith JE, Mouillesseaux KP, Bradley V, Hartland C, et al. Flt-1 (VEGFR-1) coordinates discrete stages of blood vessel formation. Cardiovasc Res. 2016;111(1):84-93.

122. Zeng $G$, Bautch VL. Differentiation and dynamic analysis of primitive vessels from embryonic stem cells. Methods Mol Biol. 2009;482:333-44.

123. Keller G. Embryonic stem cell differentiation: emergence of a new era in biology and medicine. Genes Dev. 2005;19(10):1129-55.

124. Risau W, Sariola H, Zerwes HG, Sasse J, Ekblom P, Kemler R, et al. Vasculogenesis and angiogenesis in embryonic-stem-cell-derived embryoid bodies. Development. 1988;102(3):471-8.

125. Kusuma S, Shen YI, Hanjaya-Putra D, Mali P, Cheng L, Gerecht S. Selforganized vascular networks from human pluripotent stem cells in a synthetic matrix. Proc Natl Acad Sci U S A. 2013;110(31):12601-6.

126. Jakobsson L, Domogatskaya A, Tryggvason K, Edgar D, Claesson-Welsh L. Laminin deposition is dispensable for vasculogenesis but regulates blood vessel diameter independent of flow. FASEB J. 2008;22(5):1530-9.

127. Chappell JC, Taylor SM, Ferrara N, Bautch VL. Local guidance of emerging vessel sprouts requires soluble Flt-1. Dev Cell. 2009;17(3):377-86.

128. Nakatsu MN, Hughes CC. An optimized three-dimensional in vitro model for the analysis of angiogenesis. Methods Enzymol. 2008:443:65-82.

129. Nakatsu MN, Davis J, Hughes CC. Optimized fibrin gel bead assay for the study of angiogenesis. J Vis Exp. 2007;3:186.

130. Koh W, Stratman AN, Sacharidou A, Davis GE. In vitro three dimensional collagen matrix models of endothelial lumen formation during vasculogenesis and angiogenesis. Methods Enzymol. 2008;443:83-101.

131. Masumura T, Yamamoto K, Shimizu N, Obi S, Ando J. Shear stress increases expression of the arterial endothelial marker ephrinB2 in murine ES cells via the VEGF-notch signaling pathways. Arterioscler Thromb Vasc Biol. 2009; 29(12):2125-31.

132. Obi S, Yamamoto K, Shimizu N, Kumagaya S, Masumura T, Sokabe T, et al. Fluid shear stress induces arterial differentiation of endothelial progenitor cells. J Appl Physiol. 2009;106(1):203-11.
133. Kang H, Bayless K, Kaunas R. Fluid shear stress modulates endothelial cell invasion into three-dimensional collagen matrices. Am J Physiol Heart Circ Physiol. 2008;295(5):H2087-97.

134. Garcia-Cardena G, Comander J, Anderson KR, Blackman BR, Gimbrone MA Jr. Biomechanical activation of vascular endothelium as a determinant of its functional phenotype. Proc Natl Acad Sci U S A. 2001;98(8):4478-85.

135. Skalak TC, Price RJ. The role of mechanical stresses in microvascular remodeling. Microcirculation. 1996;3(2):143-65.

136. Hahn C, Schwartz MA. Mechanotransduction in vascular physiology and atherogenesis. Nat Rev Mol Cell Biol. 2009;10(1):53-62.

137. Darden J, Payne LB, Zhao H, Chappell JC. Excess vascular endothelial growth factor-A disrupts pericyte recruitment during blood vessel formation. Angiogenesis. 2019;22(1):167-83. https://doi.org/10.1007/s10456018-9648-z. Epub 2018 Sep 20

138. Zhou X, Gallicano Gl. Microvascular tubes derived from embryonic stem cells sustain blood flow. Stem Cells Dev. 2006;15(3):335-47.

139. Kawasaki T, Kitsukawa T, Bekku Y, Matsuda Y, Sanbo M, Yagi T, et al. A requirement for neuropilin-1 in embryonic vessel formation. Development. 1999;126(21):4895-902.

140. Shalaby F, Rossant J, Yamaguchi TP, Gertsenstein M, Wu XF, Breitman ML, et al. Failure of blood-island formation and vasculogenesis in Flk-1-deficient mice. Nature. 1995;376(6535):62-6.

141. Gerhardt H, Golding M, Fruttiger M, Ruhrberg C, Lundkvist A, Abramsson A, et al. VEGF guides angiogenic sprouting utilizing endothelial tip cell filopodia. J Cell Biol. 2003;161(6):1163-77.

142. Akbari E, Spychalski GB, Song JW. Microfluidic approaches to the study of angiogenesis and the microcirculation. Microcirculation. 2017;24(5). https://doi. org/10.1111/micc.12363.

143. Vickerman V, Blundo J, Chung S, Kamm R. Design, fabrication and implementation of a novel multi-parameter control microfluidic platform for three-dimensional cell culture and real-time imaging. Lab Chip. 2008;8(9): 1468-77.

144. Davis GE, Senger DR. Endothelial extracellular matrix: biosynthesis, remodeling, and functions during vascular morphogenesis and neovessel stabilization. Circ Res. 2005;97(11):1093-107.

145. Mannino RG, Pandian NK, Jain A, Lam WA. Engineering "Endothelialized" microfluidics for investigating vascular and hematologic processes using non-traditional fabrication techniques. Curr Opin Biomed Eng. 2018:5:13-20.

146. Murfee WL, Peirce SM. Microfluidics Technologies and Approaches for Studying the Microcirculation. Microcirculation. 2017;24(5). https://doi.org/ 10.1111/micc.12377

147. Sobrino A, Phan DT, Datta R, Wang X, Hachey SJ, Romero-Lopez M, et al. 3D microtumors in vitro supported by perfused vascular networks. Sci Rep. 2016;6:31589.

148. Moya ML, Hsu YH, Lee AP, Hughes CC, George SC. In vitro perfused human capillary networks. Tissue Eng Part C Methods. 2013;19(9):730-7.

149. Phan DTT, Wang X, Craver BM, Sobrino A, Zhao D, Chen JC, et al. A vascularized and perfused organ-on-a-chip platform for large-scale drug screening applications. Lab Chip. 2017;17(3):511-20.

150. Campisi M, Shin Y, Osaki T, Hajal C, Chiono V, Kamm RD. 3D self-organized microvascular model of the human blood-brain barrier with endothelial cells, pericytes and astrocytes. Biomaterials. 2018;180:117-29.

151. Sefidgar M, Soltani M, Raahemifar K, Sadeghi M, Bazmara H, Bazargan M, et al. Numerical modeling of drug delivery in a dynamic solid tumor microvasculature. Microvasc Res. 2015;99:43-56.

152. Welter $\mathrm{M}$, Rieger $\mathrm{H}$. Interstitial fluid flow and drug delivery in vascularized tumors: a computational model. PLoS One. 2013;8(8):e70395.

153. Tsai M, Kita A, Leach J, Rounsevell R, Huang JN, Moake J, et al. In vitro modeling of the microvascular occlusion and thrombosis that occur in hematologic diseases using microfluidic technology. J Clin Invest. 2012;122(1):408-18.

154. Tourovskaia A, Fauver M, Kramer G, Simonson S, Neumann T. Tissue-engineered microenvironment systems for modeling human vasculature. Exp Biol Med (Maywood). 2014:239(9):1264-71.

155. Zervantonakis IK, Hughes-Alford SK, Charest JL, Condeelis JS, Gertler FB, Kamm RD. Three-dimensional microfluidic model for tumor cell intravasation and endothelial barrier function. Proc Natl Acad Sci U S A. 2012:109(34):13515-20

156. Fukumura D, Kloepper J, Amoozgar Z, Duda DG, Jain RK. Enhancing cancer immunotherapy using antiangiogenics: opportunities and challenges. Nat Rev Clin Oncol. 2018;15(5):325-40. 
157. Sun X, Kanwar JR, Leung E, Lehnert K, Wang D, Krissansen GW. Gene transfer of antisense hypoxia inducible factor-1 alpha enhances the therapeutic efficacy of cancer immunotherapy. Gene Ther. 2001;8(8):638-45.

158. Walpole J, Papin JA, Peirce SM. Multiscale computational models of complex biological systems. Annu Rev Biomed Eng. 2013;15:137-54.

159. Walpole J, Chappell JC, Cluceru JG, Mac Gabhann F, Bautch VL, Peirce SM. Agentbased model of angiogenesis simulates capillary sprout initiation in multicellular networks. Integr Biol (Camb). 2015;7(9):987-97.

160. Bentley K, Gerhardt H, Bates PA. Agent-based simulation of notch-mediated tip cell selection in angiogenic sprout initialisation. J Theor Biol. 2008:250(1):25-36.

161. Logsdon EA, Finley SD, Popel AS, Mac GF. A systems biology view of blood vessel growth and remodelling. J Cell Mol Med. 2014;18(8):1491-508.

162. Stefanini MO, Wu FT, Mac Gabhann F, Popel AS. The presence of VEGF receptors on the luminal surface of endothelial cells affects VEGF distribution and VEGF signaling. PLoS Comput Biol. 2009;5(12):e1000622.

163. Mac Gabhann F, Popel AS. Systems biology of vascular endothelial growth factors. Microcirculation. 2008;15(8):715-38.

164. Murfee WL, Sweat RS, Tsubota K, Mac Gabhann F, Khismatullin D, Peirce SM. Applications of computational models to better understand microvascular remodelling: a focus on biomechanical integration across scales. Interface Focus. 2015;5(2):20140077.

165. Al-Shammari AA, Gaffney EA, Egginton S. Modelling capillary oxygen supply capacity in mixed muscles: capillary domains revisited. J Theor Biol. 2014;356:47-61.

166. Stylianopoulos T, Munn LL, Jain RK. Reengineering the physical microenvironment of tumors to improve drug delivery and efficacy: from mathematical modeling to bench to bedside. Trends Cancer. 2018;4(4):292-319.

167. Zhang L, Strouthos CG, Wang Z, Deisboeck TS. Simulating brain tumor heterogeneity with a multiscale agent-based model: linking molecular signatures, phenotypes and expansion rate. Math Comput Model. 2009;49(1-2):307-19.

168. Ubezio B, Blanco RA, Geudens I, Stanchi F, Mathivet T, Jones ML, et al. Synchronization of endothelial DII4-notch dynamics switch blood vessels from branching to expansion. Elife. 2016;5. https://doi.org/10.7554/eLife.12167.

169. Jakobsson L, Franco CA, Bentley K, Collins RT, Ponsioen B, Aspalter IM, et al. Endothelial cells dynamically compete for the tip cell position during angiogenic sprouting. Nat Cell Biol. 2010;12(10):943-53.

170. Bentley K, Mariggi G, Gerhardt H, Bates PA. Tipping the balance: robustness of tip cell selection, migration and fusion in angiogenesis. PLoS Comput Biol. 2009;5(10):e1000549.

171. Hellstrom M, Phng LK, Hofmann JJ, Wallgard E, Coultas L, Lindblom P, et al. DII4 signalling through Notch1 regulates formation of tip cells during angiogenesis. Nature. 2007:445(7129):776-80.

172. Falcon BL, Hashizume H, Koumoutsakos P, Chou J, Bready JV, Coxon A, et al. Contrasting actions of selective inhibitors of angiopoietin-1 and angiopoietin-2 on the normalization of tumor blood vessels. Am J Pathol. 2009;175(5):2159-70

173. Eilken HM, Dieguez-Hurtado R, Schmidt I, Nakayama M, Jeong HW, Arf H, et al. Pericytes regulate VEGF-induced endothelial sprouting through VEGFR1. Nat Commun. 2017:8(1):1574.

174. Cao R, Xue Y, Hedlund EM, Zhong Z, Tritsaris K, Tondelli B, et al. VEGFR1mediated pericyte ablation links VEGF and PIGF to cancer-associated retinopathy. Proc Natl Acad Sci U S A. 2010;107(2):856-61.

175. Fruttiger M. Development of the mouse retinal vasculature: angiogenesis versus vasculogenesis. Invest Ophthalmol Vis Sci. 2002:43(2):522-7.

176. Shih SC, Ju M, Liu N, Smith LE. Selective stimulation of VEGFR-1 prevents oxygen-induced retinal vascular degeneration in retinopathy of prematurity. J Clin Invest. 2003;112(1):50-7.

177. Matsumoto K, Azami T, Otsu A, Takase H, Ishitobi H, Tanaka J, et al. Study of normal and pathological blood vessel morphogenesis in Flt1-tdsRed BAC Tg mice. Genesis. 2012;50(7):561-71.

178. Luo L, Uehara H, Zhang X, Das SK, Olsen T, Holt D, et al. Photoreceptor avascular privilege is shielded by soluble VEGF receptor-1. Elife. 2013;2: e00324.

179. Zeisel A, Munoz-Manchado AB, Codeluppi S, Lonnerberg P, La Manno G, Jureus $A$, et al. Brain structure. Cell types in the mouse cortex and hippocampus revealed by single-cell RNA-seq. Science. 2015;347(6226):1138-42.

180. Chen TT, Luque A, Lee S, Anderson SM, Segura T, Iruela-Arispe ML. Anchorage of VEGF to the extracellular matrix conveys differential signaling responses to endothelial cells. J Cell Biol. 2010;188(4):595-609.

181. Sagare AP, Sweeney MD, Makshanoff J, Zlokovic BV. Shedding of soluble plateletderived growth factor receptor-beta from human brain pericytes. Neurosci Lett. 2015;607:97-101
182. Hutter-Schmid B, Humpel C. Platelet-derived growth factor receptor-beta is differentially regulated in primary mouse Pericytes and brain slices. Curr Neurovasc Res. 2016;13(2):127-34

183. Durham JT, Dulmovits BM, Cronk SM, Sheets AR, Herman IM. Pericyte chemomechanics and the angiogenic switch: insights into the pathogenesis of proliferative diabetic retinopathy? Invest Ophthalmol Vis Sci. 2015;56(6): 3441-59.

184. Berthiaume AA, Grant RI, McDowell KP, Underly RG, Hartmann DA, Levy M, et al. Dynamic remodeling of Pericytes in vivo maintains capillary coverage in the adult mouse brain. Cell Rep. 2018;22(1):8-16.

185. Secomb TW, Alberding JP, Hsu R, Dewhirst MW, Pries AR. Angiogenesis: an adaptive dynamic biological patterning problem. PLoS Comput Biol. 2013; 9(3):e1002983.

186. Grimes DR, Kannan P, Warren DR, Markelc B, Bates R, Muschel R, et al. Estimating oxygen distribution from vasculature in three-dimensional tumour tissue. J R Soc Interface. 2016;13(116). https://doi.org/10.1098/rsif. 2016.0070.

187. Secomb TW. Krogh-cylinder and infinite-domain models for washout of an inert diffusible solute from tissue. Microcirculation. 2015;22(1):91-8.

188. Bang S, Lee SR, Ko J, Son K, Tahk D, Ahn J, et al. A low permeability microfluidic blood-brain barrier platform with direct contact between Perfusable vascular network and astrocytes. Sci Rep. 2017:7(1):8083.

189. Ito H. No-reflow phenomenon and prognosis in patients with acute myocardial infarction. Nat Clin Pract Cardiovasc Med. 2006:3(9):499-506.

190. Eeckhout E, Kern MJ. The coronary no-reflow phenomenon: a review of mechanisms and therapies. Eur Heart J. 2001;22(9):729-39.
Ready to submit your research? Choose BMC and benefit from:

- fast, convenient online submission

- thorough peer review by experienced researchers in your field

- rapid publication on acceptance

- support for research data, including large and complex data types

- gold Open Access which fosters wider collaboration and increased citations

- maximum visibility for your research: over $100 \mathrm{M}$ website views per year

At $\mathrm{BMC}$, research is always in progress.

Learn more biomedcentral.com/submissions 